Western University Scholarship@Western

Aboriginal Policy Research Consortium International (APRCi)

2000

\title{
Republicanism and aboriginal peoples
}

Mark Francis

Follow this and additional works at: https://ir.lib.uwo.ca/aprci

Part of the Other Political Science Commons

Citation of this paper:

Francis, Mark, "Republicanism and aboriginal peoples" (2000). Aboriginal Policy Research Consortium International (APRCi). 342. https://ir.lib.uwo.ca/aprci/342 
This article was downloaded by: [University of Western Ontario]

On: 07 December 2012, At: 07: 18

Publisher: Routledge

Informa Ltd Registered in England and Wales Registered Number: 1072954 Registered office: Mortimer House, 37-41 Mortimer Street, London W1T 3J H, UK

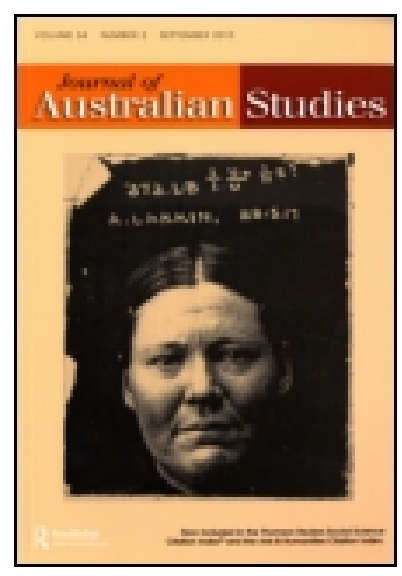

\section{J ournal of Australian Studies}

Publication details, including instructions for authors and subscription information: http:// www.tandfonline.com/loi/ rjau20

\section{Republicanism and aboriginal peoples}

Mark Francis $^{\text {a }}$

${ }^{a}$ Associate Professor of Political Science, University of Canterbury, Christchurch, New Zealand

Version of record first published: 18 May 2009.

To cite this article: Mark Francis (2000): Republicanism and aboriginal peoples, J ournal of Australian Studies, 24:64, 153-165

To link to this article: http:// dx. doi.org/ 10.1080/14443050009387567

\section{PLEASE SCROLL DOWN FOR ARTICLE}

Full terms and conditions of use: http://www.tandfonline.com/page/terms-and-conditions

This article may be used for research, teaching, and private study purposes. Any substantial or systematic reproduction, redistribution, reselling, loan, sub-licensing, systematic supply, or distribution in any form to anyone is expressly forbidden.

The publisher does not give any warranty express or implied or make any representation that the contents will be complete or accurate or up to date. The accuracy of any instructions, formulae, and drug doses should be independently verified with primary sources. The publisher shall not be liable for any loss, actions, claims, proceedings, demand, or costs or damages whatsoever or howsoever caused arising directly or indirectly in connection with or arising out of the use of this material. 


\section{R a c e $\mathrm{Nat}$ ion}




\title{
Republicanism and Aboriginal Peoples
}

\author{
Mark Francis
}

A constitutional framework could protect the freedom of Aboriginal peoples, but the actual Australian constitution has seldom done so. Aborigines did not gain full Australian citizenship until the 1960s. In 1962 legislation was passed which allowed all adult Aborigines to vote, and in 1967 there was an amendment to the 1901 Constitution as a result of which the Australian federal government was enabled to pass laws with respect to Aborigines. The 1962 change is self-explanatory while the 1967 one can be best explained as giving the Canberra government the power to intervene on behalf of Aborigines against state governments in Western Australia and Queensland where the treatment of Aborigines was most overtly racist. It is popularly believed that these two legislative changes gave Aborigines citizenship rights which the founding constitution had withheld from them. However, a more accurate perception would be that there was no significant change in the states of Aborigines in 1901, but that the federal government was a simple continuation of the well-established Australian colonial precedent of denying to Aborigines the rights and privileges possessed by most other British subjects in the sub-continent. That is, all separate colonial governments in the colonial period had similar legislation in place which ensured that Aborigines were subject to special and repressive laws and regulations.

These denied them basic rights such as freedom of movement, free bargaining for employment, and free choice of a marriage partner. These colonial governments also directly repressed Aborigines by making them subject to special curfews and to discipline for insubordination. In other words, the 1901 constitution was a non-event in the history of Aboriginal citizenship because the exclusion of indigenous people from Australian public life was a well-established custom which the constitution avoided addressing. The federal constitution, assigned the status and the rights of the Aboriginal peoples to the new state governments in such a way as to avoid disturbing their laws and administrative practices. All the Australian colonies (except for Tasmania which claimed to have no Aborigines) possessed administrative apparatus which rigidly controlled Aborigines in segregated facilities. After federation, the new states enforced bureaucratic governance upon Aborigines in an increasingly rigid process which reached its high point during the 1930s. However, even after the 1930s Aborigines were controlled. For example, in Western Australia under the Natives (Citizenship Rights) Act 1944, some Aborigines were allowed to possess citizenship, but this status would be lost if the Aboriginal citizen contracted a disease such as leprosy or syphilis. The Aboriginal citizen was also required to carry his certificate of citizenship with a photograph of the holder attached. Such limitations, which existed until the federal changes in the 1960s, ' raise the question what theoretical citizenship might have been in Australia. It is common for political theorists to assume that citizenship might mean the right to participate 
in the political processes, as someone who both rules and is ruled. This assumption does not reflect the condition of Aboriginal citizens in Australia. They were not treated as equals, nor did they participate in government.

From the perspective of its Aboriginal peoples, Australian citizenship was based on the politics of exclusion. ${ }^{2}$ Civic membership was a matter of legally defining who was included, and who was excluded, from the community. The definitional process could be quite arbitrary. For example, in the colony of Victoria after 1886 'half-castes' were forcibly removed from government-administered aboriginal stations and denied supporting benefits. This was done to make them 'free and equal citizens', a status denied to the 'aboriginal natives' who remained. ${ }^{3}$ The status of a citizen was more a matter of simple definition than a term which referred to a citizen's political function or personal qualities. To be included a citizen did not have to participate actively in politics. To be excluded did not mean one received no benefits from state; it meant that one did not receive the benefits of citizenship. This is an important point, because, as will be seen later, the quality of Australian citizenship should not be confused with the possession of independence or the avoidance of dependency. Both white Australians and Aboriginal peoples were dependent upon benefits.

Aborigines received special benefits to which ordinary Australian citizens were not entitled, but few were permitted to vote, and none was entitled to receive the general benefits, such as the old-age pension and the maternity allowance, which were the citizenship rights claimed by white Australians after the first world war. This kind of citizenship was a prescriptive matter, and did not depend on further considerations. For example, it was not given as a reward for duties. This meant that Aborigines who had borne arms in the first world war could not subsequently claim citizenship benefits. For white Australians, equal entitlement was a product of democracy, but this form of equality meant nothing across ethnic boundaries. The cost of Aborigines receiving food, shelter and medical treatment could not be traded off against general benefits such as the maternity allowance. No one was interested in calculating whether or not an individual Aborigine received more or less in monetary value than a white Australian because to be in receipt of citizenship entitlements was proof of an ethnic identity which Aborigines could not share. It was entitlement, rather than participation, which became the criterion for defining citizenship.

The fact that democratic citizenship was based on entitlement has tended to be ignored by modern scholars who find it easier to discuss citizenship as a matter of participation. While it is true that the theoretical literature on democratic participation has been expertly worked and is convenient to use, it produces few useful and innovative strategies for thinking about how Aboriginal peoples can pursue freedom, and be protected against the majority of Australians. Even if the formal basis of Australian law and politics had been more extensively democratic in the past, this would not have mitigated the mistreatment of Aboriginal peoples. The politicians and officials controlling the institutions which dominated the Aboriginal people were supported by the majority of Australian voters. It was likely that officials were less racist than ordinary white Australians. For example, in small New South Wales towns, attempts by police officers and school inspectors during the early twentieth century to enrol Aboriginal pupils in a school were defeated by direct democracy. Meetings of white parents maintained the right for 'exclusion on demand' between 
1902 and 1937. This 'right' meant that a democratic demand for the exclusion of an aboriginal child would be accepted by the state minister of education as an automatic decision. The situation was changed in 1937 when a cross-grained school inspector forced a minister to stand firm against white parents. ${ }^{5}$ The $1930 \mathrm{~s}$ also saw a reform in Western Australia which protected Aborigines by reducing popular participation. That is, a 1936 act abolished trial by jury in proceedings against whites who were charged with assaulting Aborigines. ${ }^{6}$ Demands for harsh treatment of Aborigines were popular, while pressure for better treatment of Aborigines was often led by unrepresentative figures such as academics and church leaders. Even more telling is that effective pressure for the better treatment of Aborigines after the first world war was external to Australia, and came from the British imperial government - primarily because it was long concerned with the treatment of Indians who had been defined as 'aboriginal natives' in Australia.' This suggests that before the 1967 referendum, which favoured constitutional reform on the subject of Aboriginal citizenship, higher amounts of democratic participation in Australia would have been repressive.

\section{II}

Since participation and equality are so central to liberal democracy, and since they have not served to protect the freedom of Aboriginal peoples, it is suggested here that liberal democratic theory be abandoned rather than repaired in the area of ethnic relations. That is, it might be preferable to avoid the language of liberal democratic citizenship.

If you view citizenship as a device to protect freedom, rather than as a means of exercising power, then you might want to avoid defining citizens as people who both rule and are ruled. The latter definition owes a lot to twentieth-century readings of classical political theory which attempt to legitimize the actions of the state to the individual. Instead of this, it is proposed that a citizen should be considered as a person who enjoys certain specified rights in a state, and that these rights should not be easily infringed even for a legitimate public good. It is also proposed that the freedoms of citizens should chiefly refer to specific practical liberties (such as freedom of movement, freedom to bargain for the sale of their own labour, and freedom to marry whom one chooses).

At first, this approach sounds anachronistic or backward. That is, to recommend the removal of practical and almost physical restraints - such as ensuring free movement - sounds primitive in comparison to the kind of freedom attached to conventional theories of citizenship. After all, it can plausibly be argued that such freedoms mean little unless they are closely bound up with economic and social rights which are products of states with developed welfare systems. However, it should be remarked that these sorts of rights allow for specific liberties of the kind mentioned above to be infringed providing that some public good is under consideration. This consideration is particularly important when Aboriginal liberties are concerned because Aborigines were subject to special regulations on basic freedoms in a way other citizens were not. For instance, a 1897 Queensland act specifically restricted Aborigines in their freedom of movement. The effect of this kind of regulation was to reduce personal autonomy and restrict freedom of choice, but its intent was to protect Aboriginals by stopping the sale of opium and liquor. ${ }^{8}$ That is, while a social 
good was intended, there was no restriction on the means with which to accomplish this. There was a similar rationale behind special administrative regulations promulgated by officials who punished Aboriginal people for minor infringements. For example, the latter could have their food supply restricted because it was intended that this would have some 'good' effect such as making the people disciplined and more like Europeans.

The fact that restrictions on Aboriginal freedom were administered by officials rather than by the general populace or their elected representatives was not significant. The officials faithfully mirrored the feeling of the greater community that Aboriginal peoples needed to be controlled. This leads to the conclusion that it was not beneficial for the Aboriginal peoples to live in a free state such as the Commonwealth of Australia. Most Australians did not wish to provide Aboriginal peoples with what Quentin Skinner has called the subsidiary benefits of freedom. That is, they were not provided with the benefits of enjoying their possessions freely and of living without fear. ${ }^{9}$ Nor did Aboriginal peoples escape from the kind of personal subjection the absence of which, traditionally, was the chief benefit enjoyed by citizens of free states. ${ }^{10}$

The extremely coerced position of Aborigines suggests that their lives would have been improved if their freedoms had not depended upon their potential participation in the politics of a free state, but had been guaranteed to them as a series of specific liberties. Or, to put it another way, it would have been preferable if their liberties did not depend upon a theory of citizenship in which the citizen both ruled and was ruled. For Aboriginal peoples a particular freedom, such as freedom of movement, might be qualitatively better than a guarantee of electoral franchise which would bind them to the larger community, and which could be used to legitimize restrictions on freedom.

There is reason to believe that Aborigines held freedom of movement to be such an important value that its removal would be worse than any other loss. They considered imprisonment to be extremely onerous. In the course of the 1897 debate upon the legislation which restricted Aboriginal liberties, the Queensland Home Secretary remarked that imprisonment for an Aborigine for three years was as harassing as ten years for a white man. This remark seems to have been part of a parliamentary show of slight remorse for brutal treatment of Aborigines in the past, but the Queensland parliament did not consider redressing the situation. " Whether it was felt more painfully or not, Aborigines have suffered restriction on their movement through imprisonment much more than white Australians. A century after this Queensland debate indigenous juveniles detained in Australia comprise 33 per cent of all juveniles in detention even though they are only three percent of the population. ${ }^{12}$ (The Queensland government figures for indigenous juveniles are almost twice the national average at 62 per cent). As for Aboriginal people in general (that is, including adults) they are 26 times more likely to be incarcerated than non-Aboriginal Australians. ${ }^{13}$ There is no reason to suppose that Aboriginal peoples whose freedom of movement is restricted so frequently would accept this more easily if they were told that it had been lawfully (or non-arbitrarily) imposed. Instead, they would be more likely to agree with Thomas Hobbes in discrediting the idea that liberty is associated with a free political state. They would also agree with Hobbes that: 'The freedom of a man accordingly consists in nothing more than the fact that his body is not hindered from action according to its powers'. ${ }^{4}$ 
If one wishes to maintain the freedom of Aborigines then it is important to find a political framework which will guarantee specific liberties - such as freedom of movement. It should be important that Aboriginal people not be hindered from action even if some social good can be accomplished by restraint. If restraints on Aboriginal peoples were prevented constitutionally this would curtail administrative actions such as the early twentieth-century practice of imprisoning Aboriginal witnesses to ensure their attendance at a criminal trial. It would also have stopped the neck-chaining of non-criminal Aborigines who were suffering from leprosy. ${ }^{\text {is }}$ (These chains weighed between 28 and 84 ounces and their use on Aboriginal criminals was defended as late as the1950s, though handcuffs were used to control non-Aboriginal people by that time. ${ }^{16}$ ) Such controlling practices should be ruled out even if an important social good such as the administration of justice, or the improvement of health, is thereby prevented. Such a constitutional prohibition would not only resist popular infringements of Aboriginal liberties, but would work against the pre-democratic notion of citizenship which saw the citizen as a person who was subject to the laws of the state. This sort of definition was underpinned by a theory of the state in which the group could find its unity in submission to the law. ${ }^{17}$ It is unlikely that this older formulation of citizenship would be attractive today, but it has a dangerous resemblance to the modern liberal democratic one in sourcing citizenship in the identity of the whole society. Both the democratic and the 'legal' definitions of citizenship overlook the fact that the interests of indigenous peoples have not been represented in the unity or identity of the society. ${ }^{18}$ This suggests that the whole question of Aboriginal freedom has to be considered afresh; it is not enough to re-code it in the language of classical political theory.

That is, a great obstacle to rescuing Aboriginal liberties is the way in which classically-based citizenship theories are deployed in current political discussion. From the perspective of Aboriginal liberty, conventional theories of citizenship are similar whether they are traced to Aristotle and Rousseau or to neo-roman writers. In Chesterman and Galligan, Aristotle and Rousseau are made to say that political participation and equality are the most important qualities of citizenship. These qualities can be summed up by a statement in which a citizen is someone who both rules and is ruled. ${ }^{19}$ Quentin Skinner anchors his theory of citizenship in a Roman rather than a Greek past, but the result is the same. $\mathrm{He}$ sees neo-roman texts as arguing that 'it is only possible to escape from personal servitude if you live as an active citizen under a representative form of government'.$^{20}$ The point these writers have in common is that they see freedom as growing from membership in a free state. From the perspective of Aboriginal liberties, there is a major flaw to this theory; it will always work to repress specific Aboriginal liberties. I will call this egalitarian and participatory theory of citizenship liberalism, ${ }^{21}$ and argue that it does not protect minorities, and should not be re-constructed as if it could. Instead, aboriginal peoples should rely on a type of republicanism which has shed its classical roots.

\section{III}

There are two available theories which can be used to protect indigenous people: liberalism and republicanism. Both of these theories are difficult to apply in this way, but, as I hope to show, republicanism is to be preferred over liberalism. The 
former can be modified in such a way as to protect the liberties of indigenous people, while the latter is less amenable to be used in this way. Republicanism, at least when it is an ethically informed political theory, has been absent from Australian policies whereas liberalism has often been invoked and has been shown to possess several features which systematically work to disadvantage Aboriginal peoples.

Liberalism is problematic when applied to indigenous people because it is usually expressed in a liberal democratic form in which equality and participation are given special prominence. For example, when John Rawls wished to establish a principle of liberal legitimacy he refers to two special features of the political relationship between democratic citizens. First, he says 'it is a relationship with the basic structure of the society into which they are born and in which they normally lead a complete life'. Second, Rawls considers democratic political power as a coercive power belonging to a public collective which is composed of free and equal citizens. ${ }^{22}$ While some twentieth-century liberals, such as Hayek, do not see quality of individual life as dependent upon the structure of society, enough of them formulate citizenship in the way Rawls has done for that to be considered typical. ${ }^{23}$

As has already been mentioned, a theory of citizenship which stresses equality and participation is difficult to reconcile with the position of Aboriginal peoples in Australia. Histories of the administrative treatment of Aboriginal peoples are straight-forward accounts of control, not of equality and participation. ${ }^{24}$ Oral history accounts confirm that for Aboriginal peoples the 'relationship with the basic structure of the society into which they are born' was one of domination. This feature of Aboriginal lives cannot be dealt with by liberals because they do not possess an extra concern to reduce domination. ${ }^{25}$ I suggest that liberals do not have this extra concern because of four features of their political philosophy. These features have particular importance in making liberalism unsuitable as a basis for the constitutional protection of indigenous minorities.

First, liberals consider lack of domination as a social good which can be offset against another good, participation. That is, although modern liberals might share John Stuart Mill's desire to resist social pressure to restrict individual choices, they have an equal desire to encourage participation. If there is a conflict between these two goals, then the liberal is not strongly biased in favour of non-domination. Yet non-domination seems to be the chief need of indigenous people who live in liberal democratic states.

Second, as twentieth-century critics of liberalism have observed, liberals are centred upon a belief in the unencumbered self which is a notion of identity detached from further aims or goals. ${ }^{26}$ This liberal belief undermines the conception of an indigenous minority as something which possess a group identity. That is, liberals resolve group identity into an aggregate collection of individual identities which can then be used to further a principle of equality. Indigenous groups become collections of individuals whose 'real' interests can be counted, and weighed against those of individuals from the majority group. This is an artificial equality and militates against a constitutional attempt to erect firm barriers which would protect Aboriginal peoples from types of domination which are not directed against reducing the independence and choice of the unencumbered self.

Third, in the administrative treatment of Aboriginal peoples, liberal goals did not protect Aboriginal peoples. There were two reasons this did not happen. In the nineteenth century, liberals simply exempted Aboriginal peoples from consideration, while, in the twentieth century, liberals did consider Aboriginal peoples, but did so in 
such a way as to restrict their liberties. To take the past first, colonial liberals did not transfer the ideal of social development (proposed by John Stuart Mill and his progressive followers in England) to the treatment of Aboriginal peoples. While English 'developmental' liberalism had been concerned to civilise members of the working classes so they take their full place as citizens, Australian liberals did not see education and other development as providing a future civic role for Aborigines. The only entitlement they wished to provide Aborigines was survival in isolation and protection from Europeans. ${ }^{27}$ (Colonial liberals, like most other nineteenth-century Australians, did not consider the future of Aboriginal peoples because they did not believe there would be one.) Australian colonial liberals provide an interesting example of Quentin Skinner's argument that liberals were only concerned to avoid interference when it was caused by intentional coercion of body or will. Colonial liberal protection of Aborigines was circumscribed exactly in that way. ${ }^{28}$ Liberals limited themselves to preventing European coercion of Aboriginal peoples; they did not see themselves as obliged to ensure that Aboriginal peoples possessed the liberty to carry out any particular physical activity. For example, in New South Wales during the early twentieth century, Aboriginal reserves were very small, yet Aboriginal freedom of movement within such reserves might be restricted. If the government agent rented a portion of the reserve to a white farmer then Aborigines could lose the freedom to walk on the rented portion. Twentieth-century liberals have considered more than the need to avoid interference as a matter of preventing coercion, but their views are also flawed. That is, modern liberal goals have often been construed as the need to force full citizenship upon people who did not wish this. An example of this was the suggestion that Aboriginal peoples would benefit if their children received educational and other development and became full members of the political community. ${ }^{29}$ This was domination because the views of Aboriginal children and parents were ignored in the planning and carrying out of this 'improvement'. There was nothing inherent in liberal doctrine in Australia which has prevented Aboriginal people from being dominated or interfered with.

Fourth, twentieth-century liberals have often viewed citizenship as the possession of entitlements regardless of whether or not those freed the recipients of benefits from domination. Entitlement to a benefit was not seen as a matter of making peoples less free. That is, there was no concern that benefits would reduce Australians from being robust self-employed citizens who were independent from the state. In other words, liberals did not see the task of citizenship as one which made people independent in their behaviour, even if the individual identity of citizens was imagined to be independent from collective goals. From the point of view of how a citizen should be treated, domination was not ruled out. The fact that Aboriginal freedoms were not protected from domination, or potential domination, meant that the choices in Aboriginal lives - in areas from employment and marriage through to which foodstuffs were allocated and in what form money could be saved - were dictated by someone else, usually a protector, a missionary or a policeman. Aborigines were in a position similar to the one resented by Philip Pettit when he was training to be a priest. ${ }^{30}$ That is, Aborigines were in total institutions and experienced a sense of systematic vulnerability and exposure to a governing will. The food, shelter and medicine which Aboriginal people received was as much a part of a system of domination as it was a product of disinterested benevolence. Aborigines were subject to arbitrary rewards and punishments at the will of the administrator who was 
protecting them. This liberal protection was structured around the idea that Aborigines would be protected from interference by whites, not from domination per se. ${ }^{31}$ Aboriginal peoples were often protected from being killed, enslaved, raped, and assaulted, but this is not enough.

\section{IV}

Republicanism can be made to work on behalf of indigenous people more easily than liberalism. However, this is not true of all varieties of theoretical republicanism. Republicanism could take a form which did not prize anti-domination as the prime value. That is, it could be formulated as to assert that the people is the master, and the state is the servant. ${ }^{32}$ Or, as with Benjamin Constant and Isaiah Berlin, republicanism could be built around a theory of democratic participation. ${ }^{33}$ However, these theories are not helpful. That is, when one is considering the interests of indigenous people these varieties of republicanism offer little protection. If the people is master, or if the chief good is mass participation in the political life of the community, then the interests of a perpetual minority will not be served. If, however, republicanism is considered as a doctrine which holds that a person should be immune to either domination or arbitrary interference then it can be modified to serve the interests of Aboriginal peoples.

Philip Pettit's republican ideas are particularly viable because they chiefly work in this way. However, his republicanism needs to be distinguished from the classical or neo-roman tradition which he admires so it can serve as a basis for the protection of Aboriginal liberties. That is, it is argued here that Pettit's views are not valuable because they depend on traditional or pre-liberal views, but because they are original in a way he does not wish to claim.

Classical republicans wanted to build a just government which was prosperous, stable over time, and militarily powerful. They also desired that legislation should aim at improving the common good of society. In order to sustain the polity, classical republicans conceived of the personality of the citizen as an independent robust person who was capable of self-sacrifice. ${ }^{34}$ While such a citizen valued nondomination (protection against the exercise of arbitrary power) this was not an end in itself; it was subordinate to a further goal which was the maintenance of a free state. However, for Pettit, the non-domination of the citizen is an end in itself. In addition, his republican citizen is not someone who is prosperous and strong enough to be a potential soldier, but a marginalized person: he refers to battered wives, aggrieved employees and indigenous people. These are similar to each other in being powerless and currently without adequate constitutional protection. ${ }^{35}$

The implications of the original aspect of Pettit's republicanism are that, unlike classical republicanism (and unlike Rawls' liberal democracy), it does not need either the individual to have a particular personality or the state to have a particular goal beyond anti-domination. Individuals may have the qualities of a good citizen, and the state may have a high degree of participation, but these are not essential. This feature of non-traditional republicanism has an important implication for the definition of the citizen. He/she is no longer to be specified as someone who both rules and is ruled. The relationship between the individual and the government is now between two entities which are without specific characteristics. For example, whether or not individuals are independently minded, or possess a rational and self-perfecting 
life plan, does not matter; as citizens of the republic their liberties will be protected regardless of their personal qualities. Similarly, the state is no longer specified in terms of positive goals. It is defined negatively as imperative needs to ensure that it will not dominate, and that it will not allow its citizens to dominate each other.

Pettit's republicanism is a stance which is both negative and radical; it contrasts sharply with recent positive attempts to incorporate indigenous groups into the general polity. For example, when Darlene Johnston specifies the relationship between such groups and the state she does so by promoting a positive goal - the well-being of individuals. She suggests that the well-being of individuals is connected with their group membership in a way that is beyond choice. That is, her account has an 'objective' quality in not being reducible to choices in the way non-traditional republicanism is. On the contrary, Johnston intends her account to distinguish between the kind of group whose membership is a product of their birth and the group which has voluntary members. ${ }^{36}$ This strategy seems to disadvantage indigenous peoples in two ways in which republicanism does not. First, it raises the danger that if membership of indigenous groups is not self-acclamation (not based on the choice of the republican citizens), but is based on 'objective' criteria, such as number of indigenous grandparents, then the state will be the entity which controls and defines who is a member of the group. Considering that, in the past, the state in Australia, like the states in New Zealand, Canada and the United States, deemed who was a member of indigenous groups, seems an area of potential concern. To combat this, republicanism would insist on the freedom of indigenous peoples to have the choice of how to exercise their citizenship. Group choice plays the same role in republicanism that individual choice does for liberalism - the self-recognition of social identity. However, the citizenship would not rest on the possession of identity. The second danger in founding indigenous citizenship on birthright rather than on voluntary choice, is that the political ideas of indigenous groups would be likely to take on a conservative cast and always opt for limited political goals. For example, if birthright - defined as uninterrupted occupation of particular sites by groups informed about traditional land tenure - becomes the main criterion for citizenship of Aboriginal peoples in Australia, this would limit citizenship to a small number and focus its operation chiefly on land claims. Many people would be excluded even if their liberties were as much in need of protection as those who could claim birthright. In addition, indigenous peoples in urban areas might choose to coalesce with others - from outside their birth groups - and the resulting new group might wish to initiate new claims to nondomination. They might, as suggested by Pettit, choose to be exempt from some obligations which are universal for the population in general. ${ }^{37}$

It is important to build non-traditional republicanism into an institutional framework. That is, freedom should be constitutionally protected rather than reserved as an extra-constitutional area in which individuals can pursue their own goals. Freedom should not be left as a laissez-faire matter. As Pettit remarks, to rely upon individuals possessing adequate reciprocal power to check others is insufficient. The state must promote non-domination. ${ }^{38}$

How and why the state should promote non-domination is perplexing. If one has jettisoned the traditional arguments about the value of the individual and about the public good of a free state, then one has to navigate without help from these comforting polar stars. However, there are advantages as well as disadvantages in originality. Non-traditional republicanism can theorize about domination today, rather than in 
the ancient world. The players on the stage can simulate modern rather than antique figures, and the scene no longer has to be a city-state in which the citizens participated in their rule. Instead, we can picture government institutions regulating the affairs of groups as well as of individuals. These institutions are agents, but they may be corporate agents rather than individual ones. They cannot be disembodied entities such as systems or networks. ${ }^{39}$ It must be possible to assign harm to particular agents. Pettit is like Godwin's Caleb Williams in insisting that particular agents oppress other people, not abstract theoretical entities such as justice. They, the agents, can dominate and need to be institutionally restrained.

Non-domination as a constitutional system will have to recognize that harm can befall groups as well as single individuals. Pettit recognizes that for members of dominated groups, such as an indigenous people, the primary political goal, nondomination, can only be achieved if the individuals band together. They should articulate their views as group grievances and group assertions. ${ }^{40}$ Only by group action will an indigenous people achieve non-domination. The non-traditional republican view is not one in which individual citizens legitimize public goods by giving their consent. Rather it is based upon the modern reality that minority politics is a relationship between the government as an agent and an articulate group with a grievance. If an indigenous people request that their freedom be protected, this cannot be satisfied by the governing agent saying that they already have their freedom because no one is interfering with them as individuals. They must be entitled to accomplish their goals as a group. Further, on occasion, they will have to be given resources with which to exercise their freedom effectively.

There will still, however, be individuals as well as groups. Membership in a minority group should be a matter of choice by the individuals who compose it. Governments should not be able to prescribe membership by stating that an individual is an Aborigine because his/her identity has been determined by an Act of Parliament or by an administrative regulation. ${ }^{41}$ Self-chosen membership will be effective citizenship, and should be exempt from interference by members of the majority group. That is, the non-traditional republican will not allow citizenship to be defined by majority-dominated assemblies in such a way as to affect the culture or claims of an indigenous people. Aboriginal citizenship is still sometimes defined in much the same way as it was in the nineteenth century. In 1983 the Commonwealth of Australia amended its legislation to make it compulsory for Aborigines to enrol and to vote in general elections. ${ }^{42}$ Presumably the change was dictated by a liberal democratic belief that equality was to be valued for its own sake, ${ }^{43}$ but equality with the white majority might not be desirable. ${ }^{44}$ There is no reason why Aboriginal peoples should accept state decisions on their citizenship. A republican constitution would restrain the state from determining the content of citzenship which individual Aboriginals might wish to adopt. In addition, the state would not be able to structure the character of its citizens to reflect a quality which the state would like to see among its citizenry. For example, it would not be allowed to educate its citizens to be, for example, independent, rational and maximising, or willing to sacrifice themselves in the interests of the state. The constitution will be silent and neutral on the ideal personality of citizens.

Non-traditional republicanism, in emphasising that Aboriginal peoples have choice in constructing their citizenship, supports a notion of cultural equality. This kind of quality implies that separate cultures will be a permanent feature inside a state, and 
that it is to be expected that this will not lead to political consensus. If an indigenous people enjoys a separate culture, it is reasonable to assume that they will frequently adopt dissident political stances. It is, therefore, imperative that they possess a voice in a public forum where their interests are given equal respect with that of the majority. The principle here is not that of democratic equality, but of equal contestability. That is, it is supposed by non-traditional republicanism that political contestability is a desirable goal in itself ${ }^{5}$ - if what is represented in such a contest are separate cultural voices, and if reasoned deliberation takes place. This constitutional suggestion is deliberately minimalist. It is not accompanied by additional criteria which need to be satisfied by contestability. That is, decisions do not have to satisfy the majority of individuals represented or efficiency criteria, though it is expected that the minority will not use its privileged position except when its vital cultural interests are at stake. ${ }^{46}$

The republican notion of citizenship - and not just aboriginal citizenship - will be a formal category, rather than being erected upon a 'natural' identity which a citizen shares with others within a state. Citizenship should not be linked to any useful communitarian values. This negative quality is an advantage, not a disadvantage. It is important that citizens not share a deep common view of the good because the absence of this will make it easier to erect constitutional constraints with which to protect Aboriginal freedoms. The formal quality of citizenship means that when it is considered from the perspective of the majority of Australians it will not be an instrument with which one can forge a national cultural identity. Since republican citizenship will equally respect individuals belonging to separate cultural groups, it itself cannot be used to foster a national identity or to exclude any subject of the state from membership in any cultural group. That is, while the state might encourage as well as protect freedoms, it is not permitted to tamper with cultural identity. To do that would conflict with the republican theory of non-domination.

In the course of the article I have attempted to avoid the word freedom in favour of freedoms or liberties. This is because I do not wish to found republicanism upon the freedom either to possess moral autonomy or to experience self-realization. That is, it seems to me that discussions of freedom often rest upon one of these positive moral notions in a way that does not promote the exercise of political freedoms or liberties. ${ }^{47}$ Such discussions also subordinate political liberties to moral freedom in a way that is suspect. It is often only a metaphor which compares an individual's sense of identity (as autonomous or self-realizing) with a larger identity possessed by a group. However, the type of republicanism I am attempting to enunciate would restrain the state from constructing identity - moral or otherwise - so it does not need to engage with this metaphor. My reason for saying this is the feeling that an ethnic group should create its own identity, but an implication of this is that I wish to keep political rationales separate from moral freedom.

The republican liberties to which I refer are specific entitlements which would allow indigenous peoples to live with few or no restraints upon their physical and cultural activities, and with some assistance which would allow them to engage in such activities if lack of resources have prevented this. How many specific liberties there are, or whether these can be ordered so that, for example, one of them always has priority over another, I cannot consider here. However, I suspect that I would not want to enumerate liberties precisely: to do that would restrict the choice-making activity of an indigenous people. In addition, I also would not want to establish a 
decision tree in which I could say that a particular liberty was always preferable to another. To do that would be analogous to suggesting that a constitutional system which protects liberties should function like a moral agent whose choices might very well be ordered in terms of priority. Liberties should be thought of as necessarily pluralistic, or as supporting multiple, and even conflicting, goals. The republican principle of non-domination should not be considered as an organising principle for liberties, but rather as a test which will help discover which of them need protection. 